
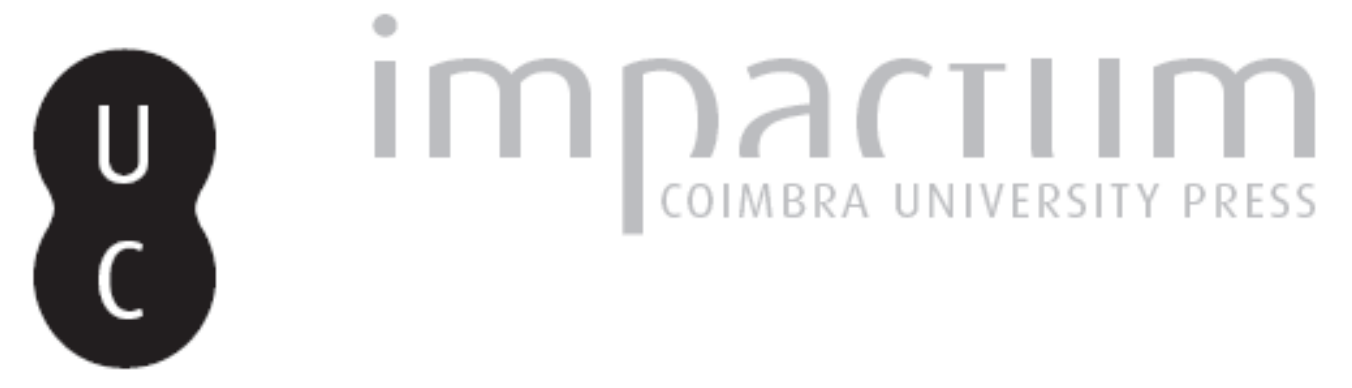

\title{
Ancient Alexandria: reflected through roman eyes
}

Autor(es): $\quad$ Clímaco, Joana Campos

Publicado por: Centro de História da Universidade de Lisboa

URL persistente:

URI:http://hdl.handle.net/10316.2/34990

DOI:

DOI:http://dx.doi.org/10.14195/0871-9527_23_11

Accessed : $\quad$ 26-Apr-2023 15:38:08

A navegação consulta e descarregamento dos títulos inseridos nas Bibliotecas Digitais UC Digitalis, UC Pombalina e UC Impactum, pressupõem a aceitação plena e sem reservas dos Termos e Condições de Uso destas Bibliotecas Digitais, disponíveis em https://digitalis.uc.pt/pt-pt/termos.

Conforme exposto nos referidos Termos e Condições de Uso, o descarregamento de títulos de acesso restrito requer uma licença válida de autorização devendo o utilizador aceder ao(s) documento(s) a partir de um endereço de IP da instituição detentora da supramencionada licença.

Ao utilizador é apenas permitido o descarregamento para uso pessoal, pelo que o emprego do(s) título(s) descarregado(s) para outro fim, designadamente comercial, carece de autorização do respetivo autor ou editor da obra.

Na medida em que todas as obras da UC Digitalis se encontram protegidas pelo Código do Direito de Autor e Direitos Conexos e demais legislação aplicável, toda a cópia, parcial ou total, deste documento, nos casos em que é legalmente admitida, deverá conter ou fazer-se acompanhar por este aviso.

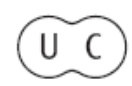



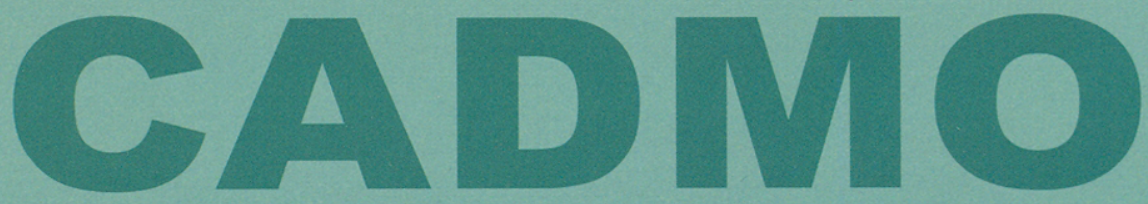

Revista de História Antiga

\author{
Centro de História \\ da Universidade de Lisboa
}

\title{
23
}

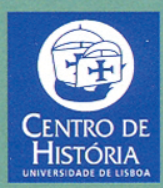

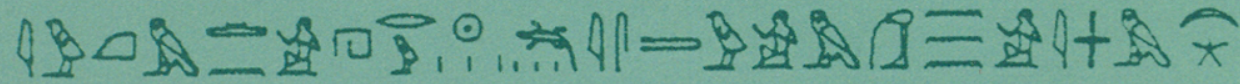

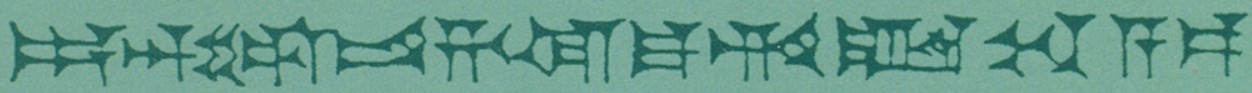
MHNIN AEI $\triangle \mathrm{E} \Theta \mathrm{EA}$ ПH$\Lambda \mathrm{HIA} \triangle \mathrm{E} \Omega$ 


\title{
ANCIENT ALEXANDRIA. REFLECTED THROUGH ROMAN EYES
}

\author{
JOANA CAMPOS CLÍMACO \\ Universidade de São Paulo \\ joanaclimaco@hotmail.com
}

\section{Resumo}

Além de Roma, nenhuma cidade no Alto Império Romano foi mais caracterizada e criticada por escritos de fora do que Alexandria. Estas imagens produzidas no período romano criaram representações da cidade que a historiografia contemporânea perpetua: uma cidade enorme, linda e turbulenta, que ficava atrás apenas de Roma. O objetivo deste artigo é discutir como as imagens associadas à grandeza e prosperidade de Alexandria ilustram uma percepção da cidade como um espelho de Roma e uma ameaça à sua hegemonia. A discussão se concentrará nas narrativas sobre a fundação, e nos escritos a respeito da cidade como um centro comercial e de lazer, todos produzidos no período romano. Minha intenção é demonstrar como a escolha dos conteúdos não era inocente, bem como a dualidade das narrativas, que enfocam nas qualidades e realizações de Alexandria, por um lado, e nos seus problemas e tendência à polêmica, por outro.

Palavras-chave: Alexandria; Egito Romano; Ptolemeus; tradição; representação.

\begin{abstract}
Apart from Rome, no city in the early Roman Empire was more characterized and criticized than Alexandria by outsiders. These images produced in Roman times created representations of the city that the contemporary historiography perpetuates: an enormous, beautiful and turbulent city, second only to Rome. The aim of this article is to discuss how these images asso-
\end{abstract}


ciated to Alexandria's greatness and prosperity illustrate a perception of the city as a mirror to Rome and a threat to its hegemony. The discussion will be concentrated on the foundation narratives, and on the writings about the city as a commercial and leisure centre, all of them produced in Roman times. The association between Alexandria and its founder was essential for the tradition to justify the city's greatness and help explain its future prosperity. My objective is to demonstrate that the selection of themes was not innocent, as was not also the duality within the narratives, that focus on Alexandria's qualities and achievements on the one hand, and on its problems and tendency to polemics, on the other.

Keywords: Alexandria; Roman Egypt; Ptolemies; tradition; representation.

Two vast cities. Two human agglomerations containing various cultures and peoples. One in the West, the other in the East. One was the capital of an enormous ascending empire. The other was the seat of the millenary kingdom of Egypt and the second larger city in the Graeco-roman world. It is not possible to understand Alexandria without reflecting about Rome and vice-versa. However, to understand Rome there are endless sources of different natures and even more richness of perceptions. Whereas to comprehend Alexandria the sources are scarce and rarely talk about their own inhabitants' point of view. Consequently, we have to depart from Rome and the plurality of domains in the Empire to consider Alexandria. No other city in the Empire, apart from Rome, offers so many testimonials from external perceptions as Alexandria. On the other hand, the scarcity of narratives of their own inhabitants that characterize and explain the city is also remarkable.

Alexandria became the most important foundation of Alexander, the Great, in the Mediterranean (founded in 331 BC) and the city was already three hundred years when it was incorporated by Octavian in $31 \mathrm{BC}$ and transformed in the capital of the Roman province of Egypt. Before the conquest, the metropolis became the second city in the inhabited world, in population and size and was outstanding in various sectors. It was also the capital of the ancient reign of Egypt, a rich and intriguing territory to Greeks and Romans for centuries, and also a rich grain supplier for Rome.

My PhD thesis investigates the multiple Alexandrian contexts legated by Graeco-roman writings elaborated between the first century $\mathrm{BC}$ and 
third century $A D$ and analyzes the images perpetuated about the city in a universe dominated by Rome. However, it is important to underline that most of these narratives are not concerned in describing and placing Alexandria, but do it as the Empire's destiny reach the city. As a result, they produce images of Alexandria in specific moments that please, bother, fascinate and threaten Rome. In this way, they form complex imperial identities for Alexandria. The main focus of my research is to understand Alexandria from representations of ancient authors, namely the images of the city propagated by the imperial elites, defining various Alexandrian identities to the ancient world.

The foundation of Alexandria by Alexander and its fast development promoted by the Ptolemaic dynasty were seen as part of its imperial identity. Therefore, it is primordial to examine how its foundation and initial history were elements that formed the picture of the city divulged to the Empire. One of the subjects most dealt with by the tradition as they characterize Alexandria is its foundation by Alexander. The enormity and prosperity of the new establishment located in the «entrance» of Egypt, already known by the Greeks for its richness and exotic habits became a commonplace in the literature. It was necessary to retrocede to the former Alexandria, in order to understand the present metropolis, so the narratives went back to its promising origin to justify its subsequent development, because its beginnings were associated with the major myth and hero of that moment: Alexander. A huge part of the potential and future development of the city is attributed to the foundation setting, probably because the authors already had in mind the Alexandria of their time (already prosperous) and could not detach this image of its foundation. Accordingly, Alexander was a visionary for having chosen a predestined site for the foundation, consequently, a considerable portion of Alexandria's future prosperity was established by the founder.

Diodorus of Sicily, author of the first century BC treats specifically of Alexandria in the context in which Rome becomes predominant in the inhabited world, while it absorbs ancient Hellenistic kingdoms to its command. The author associates the name of the city to Alexander in order to establish a chronological mark, as he counts the long duration of the Egyptian reign, since Isis and Osiris, until Alexander founded a city following his name (Bibliotheca Historica 1.23.1). In the same book, Diodorus establishes an order of the great Egyptian cities; observes that Thebes diminished with the growth of Memphis, and this one lost its 
importance after Alexander's foundation, and since then all the efforts were destined to its development (Bibliotheca Historica 1.50.6). Thereby, Alexandria enters his narrative as a new moment of Egyptian history. It was the end of an era, and the origin of a new time, an epoch when Egypt was «touched» by a memorable Greek, that would leave his impress on that millenary kingdom. Namely, Alexandria became the kings' focus of attention since it was Alexander's foundation, who conceded a Greek polis to that reign. The emphasis is on the new Greek establishment, which aggregates another identity to Egypt.

Egypt becomes relatively Hellenized with the foundation and becomes the target of Greeks attentions. Diodorus concentrated on this setting on book XVII:

He decided to found a great city in Egypt, and gave orders to the men left behind with this mission to build the city between the marsh and the sea. He laid out the site and traced the streets skilfully and ordered that the city should be called after him Alexandria. It was conveniently situated near the harbour of Pharos, and by selecting the right angle of the streets, Alexander made the city breathe with the etesian winds so that as these blow across a great expanse of sea, they cool the air of the town, and so he provided its inhabitants with a moderate climate and good health. Alexander also laid out the walls so that they were at once exceedingly large and marvellously strong. Lying between a great marsh and the sea, it affords by land only two approaches, both narrow and very easily blocked (Diodorus of Sicily, Bibliotheca Historica 17.52).

In this passage, the description of the installation of the city is initially linked to Alexander's decision, who is pictured as the main subject of the process. It is his choice that concedes to that place its memorable existence. The rationality associated to the project is noticeable, and the author emphasizes the geniality of Alexander's act.

The most underlined aspects by Diodorus are the city's territorial greatness, its defensive position, besides the choice of the adequate place. Diodorus wrote in a context of civil war, of crises in the Roman Republic and, at the same time, of Roman growth, which from a city-state, turned to an imperial city. The emphasis on Alexandria's hugeness could be an allusion to Roman expansion, which differently from Alexandria, was done in a disorderly manner.

Strabo was not familiar with Diodorus' work, but both were testimonies of a similar period of Hellenistic culture and both visited Alexandria and 
Egypt within a period of thirty years of difference (Yoyotte, 1997: 28). While Diodorus aimed to elaborate an encyclopedic narrative, Strabo was more interested in his own time, and looked back to the past only to contextualize present themes (Yoyotte, 1997: 17).

As Diodorus, Strabo looks to the foundation episode to highlight the good positioning of the city and the choice of the adequate site. He underlines the signs of good fortune and future prosperity of the city, which was revealed in demarcating the terrain. He says that when the architects were defining the city borders with chalk, its supply was over; and as the king arrived, the guardians took a bit of the barley destined to feed the workers, and in this way the streets were demarcated (Geographica 17.1.6).

Strabo adds another element apart from the adequate and defensive position and quality of the site: the presages indicating its prosperity, conceding predestination to the foundation context. We can notice here the establishment of a myth, which covers the accounts about the construction, for many circumstances collaborated to its future luck. Besides Alexander's right decision when he visualized the place, the good fortune would soon be confirmed in demarcating the terrain. Strabo enumerates the several advantages of the place, the fact that the city was situated between two seas, the Mediterranean and Lake Mariot, which considering its enormity was seen as another sea (Geographica 17.1.7). Besides Strabo's ambition to elaborate a more technical and pragmatic narrative about the city, aiming to inform the Roman men of government about each locality of the Empire, we can notice the influence of legendary elements to legitimize its importance.

As the narratives become more chronologically distant from the foundation context, more legendary and detailed they become, as we can notice in Plutarch, Quintus Curtius and Arrian, Alexanders' biographers. The construction of the city is described in a tone of extreme exaltation to his personality. Consequently, the building and his arrival in Egypt are seen as proofs of his creative genius. The accounts circulated in the first and second centuries $A D$, suggesting that the roles played by Alexander and the Ptolemies were not so negative in the Roman period, considering the importance they had to Alexandria's initial history (Krasilnikoff, 2009: 25).

According to Plutarch, Alexander's decision was inspired by Homer, since before talking about the foundation; the author observes how the poet's work was a "companion» to Alexander during his journey. After conquering Egypt and deciding to found a Greek, huge and populous city 
following his name, Plutarch narrates that Alexander was discussing with his architects about the better site, when he had a wonderful vision during his sleep, determining his choice (Vita Alexandri 26.1):

And when he saw a site of surpassing natural advantages (for it is a strip of land like enough to a broad isthmus extending between a great lagoon and a stretch of sea which terminates in a large harbour), he said he saw now that Homer was not only admirable in other ways, but also a very wise architect, and ordered the plan of the city to be drawn in conformity with this site (Plutarch, Vita Alexandri 26.4-6).

Plutarch narrates the episode of defining the city lines with the barley. It is remarkable how the author defines Alexandria as a Greek establishment. The inspiration by Homer would be a manner to legitimate its Hellenic heritage. Alexander was very familiar with the poet, who had already mentioned Egypt's prosperity in his work. Therefore, it is plausible that he had these passages in mind when he arrived in Egypt and decided to found the city (Vasunia, 2001: 255).

In the sequence, Plutarch describes the famous episode of Alexander's visit to the oracle of Amon, confirming that he would become the master of all humanity (Vita Alexandri 27.4). Thereby, Alexander had hegemony among men and Alexandria was his foundation inspired by Homer. The author could be inferring Alexandria's leadership as a Hellenistic capital in his time.

If in Strabo there is a huger emphasis on Alexander's rational decision after he viewed the site, in Plutarch the predestination of the place is reinforced. Since it was a dream that announced the best place and the signs of fortune were definitely confirmed by the demarcation episode. Homer's presence as an inspiration signalizes that the glory and success of the foundation should be attributed to the Greeks. The passage associates Homer to Alexander, and both to Alexandria's origin and in this way legitimates its identity undeniably Greek. His ideal was maybe to demonstrate the continuity and vivacity of Hellenic culture through its new Hellenistic installations.

The myths were important to offer civic ideology and strengthen the links of belonging to a city (Feeney, 1998: 53). Especially a new foundation that claimed for an identity of its own in order to unify such distinct regions needed myths to solidify its historical value. To stress the connection between Alexander and Alexandria was a way to concede antiquity and a mythical past to it, even if recent. In this way, Plutarch 
helps to attribute a Greek identity to Alexandria and make it seem natural through its association with Alexander.

Plutarch makes another observation that illustrates even more his perception of how Alexander was fundamental to define a new era in Egypt, and of the Hellenistic period as an entrance of «civilization» in the East. He narrates that the new subjects would not have been civilized, if they had not been conquered by Alexander, nor would Egypt have its Alexandria, for the foundation of cities helped eliminate savagery (Moralia. De Fortuna Alexandri 328.F.5). Thus, the author establishes a hierarchy between Alexandria and Egypt as a whole, where savagery was predominant, even though the Greek installations helped spread civility.

Arrian, another biographer that wrote in the II century AD, relates that after choosing the ideal place, Alexander defined where the central agora would be, how many temples would be built, in honor to which gods, both Greeks and Egyptians, and where the wall would surround (Anabasis Alexandri 3.1.5.2). In the sequence, he tells the demarcation legend and justifies not having reasons to doubt its veracity (Anabasis Alexandri 3.2.1). Mentioning the homage to Greek and Egyptian gods could have the intention to stress the conciliation between cultures established by Alexander. As a result, in contrast to Plutarch, he indicates Alexandria's relative belonging to Egypt as a whole and mentions the following:

It is stated that he divided the government of Egypt between many officers, both from his surprise at the nature of the country and its strength, since it did not appear to him safe to entrust the command of all Egypt to one man. The Romans, too, I think, learnt a lesson from Alexander and keep Egypt under guard, and never send anyone from the Senate as proconsul of Egypt, but only those who are enrolled among them as Knights (Arrian, Anabasis Alexandri 3.5.7).

In this passage, Arrian exposes openly the general perception of Egypt at his time, and transfers his concerns to Alexander's period, who with his wisdom, was already aware of the vigor of that place.

In the same context of writing, Pausanias also mentions the foundation, however he explains that in old times there was a small Egyptian town in the same site called Rhacotis (Graeciae descriptio. Elis 1.5.21.9.11). Therefore, he reverts to an Egyptian antiquity present in this place. On another passage, he alludes to examples of cities that were once imposing and became insignificant with time (like Thebes and Babylon). Alexandria 
was an example of a recent foundation that achieved its size and prosperity favored by fortune, which was more determinant than disasters and prosperity of cities (Graeciae descriptio. Arcadia 8.33.3). The author suggests that antiquity does not legitimate everything, and sometimes fortune is more decisive. Was he referring to the "fortune» of foundations of Greek localities in barbarian land by eminent Greek, taking «civilization» to the place? For that reason, he understands that since Alexander these sites could in fact be considered Greek.

As Greeks and representatives of the Second Sophistic, Plutarch, Arrian and Pausanias valued the deeds of the Greeks. Consequently, Alexandria was a gracious work attributed to Alexander and the Greeks. Even though the writers were writing in a «safe» context, as the city was already absorbed in the Empire, it was still a place that demanded attention. Therefore, it was necessary to justify in a mythic manner its distinction, maybe to legitimate its present importance. The authors reinforce that Alexander conceded value to that place and that after it was «touched» by a legendary Greek, all Egypt deserved more attention. In other words, the stronger the placement of its legendary foundation, the stronger its identity and evolution associated to Alexander.

The foundation setting is also commented by Latin authors as Vitruvius, Pliny the Elder, and Quintus Curtius(1). Vitruvius stresses the prosperity of the place and the presence of the architect Deinocrates in the project with Alexander (De Architectura. Praefatio 2.4). His special emphasis is in the abundance of grain and in the position of the place as a market, increased by the construction of the harbor.

Pliny points out that, besides being convinced of its ancient glories, Egypt could be proud of having had twenty thousand cities in the past and even in the present there were still a considerable number. However, he claims that the praises should be destined mostly to Alexandria. The author mentions the building of the city and antiquity of the site, called Rhacotis in old times, and highlights the presence of the architect Deinocrates, famous for his talent in many sectors (Naturalis Historiae 5.11.60-63). The author demonstrates a respectful attitude towards ancient Egypt, though his perception of the superiority of Greek culture becomes evident, for Alexandria was the best achievement in Egypt. However, the new foundation was installed in an ancient land, where there was a succession of magnificent cities. We must be cautious in detaching Alexandria of its surroundings, although it is clear that the authors do not aim to consider the presence 
of Egyptian elements. As Vitruvius, Pliny suggests that the founder should split the honors of his deeds with the architect. Mentioning the importance of the architect in the execution of the project was a way of praising the city's planning. The two accounts are less covered with mythology, and flatter Alexander more for his rationality than for his visionary nature.

The account of Quintus Curtius Rufus is the only biography preserved in Latin about Alexander and was written before the works of Plutarch and Arrian in the first century AD. His narrative about the foundation comes after a sequence of intense criticism to Egypt. The author points out that the Egyptians rapidly offered Alexander help to destroy the Persian troops, for they were a «fickle and unstable people, more inclined to start a revolution than to conquer greatness» (Historiae Alexandri Magni 4.1.28-30). When they arrived in the region of lake Mariot, he decided initially to build a city in the island, but as it did not seem huge enough for a wide establishment, he chose the site of Alexandria (Historiae Alexandri Magni 4.8.1.1).

Alexander put two men in charge of Egypt and gave them four thousand soldiers to defend the region and left another in charge of the tax gathering. Afterwards, he ordered inhabitants of the neighboring cities to go there, and in this way, he filled it with a huge population. Then he mentions the demarcation episode as a good omen, for the region would supply many lands (Historiae Alexandri Magni 4.8.6.1).

It is noticeable that his account is not so enthusiastic concerning the excellence and predestination of the place. However, he does highlight its prosperity and greatness, but stresses even more the rationality and planning of the project. Nevertheless, before the description, the first aspect emphasized by Curtius is the Egyptian tendency to rebellion and then, its agricultural richness. In this way, he notices here the two motives for which the Egyptian metropolis should be carefully watched: productivity and turbulence, an obvious reference to his contemporary Alexandria. As he was a Latin writer and chronologically closer to Augustus time it is possible that he exalts the city less and puts more emphasis on polemics, as he was «contaminated» by Augustus' propaganda. So, he makes use of the most common place version about Egypt of his time (between Tiberius and Claudius) and transfers it to the foundation moment. Another aspect that contrasts Curtius with the other biographers is that he does not define Alexandria as a Greek city, and suggests the predominance of Egyptians in its initial social composition, by mentioning the process of populating it with inhabitants of the neighboring towns. 
With its foundation, Alexandria has its name associated with one of the most prestigious men in history, fact considered by the ancients in establishing judgments about the city. The choice of the adequate place and the antiquity of the site was a type of topos in the foundation narratives of cities (Runia, 1989: 402-403). Especially in a new foundation, where the immigrants were still connected to their places of origin, Alexandria would be a common denominator for the new residents (Knox, 1985: 25). If centuries after the foundation the authors still reinforce the connection of Alexander and the city, it is credible that this aspect was strong during all Alexandria's earlier history and had survived Roman times. However, it needed to be revitalized by the Greeks of the Second Sophistic, considering so many negative accounts of Alexandria following the topos divulged by Latin authors after Augustus. The members of the Second Sophistic bring back the foundation myths in order to strengthen the Greek heritage of the new foundations (Swain, 1996: 73). As Alexander becomes a myth during the Roman period, the focus on his great deeds become stronger. Even if his ideological background had inspired his conquest of Egypt, because of all the knowledge that he had access to before arriving there, a great part of his achievements were published later, after there long term results (Vasunia, 2001: 249). Therefore, his actions were recovered and remembered under Rome, for they were even used as examples to the Empire.

After Alexander's death and the disputes among his successors for the conquered territory, there was a relative balance of power, and Ptolemy soon insists in Egypt as his option. He realized that by means of Alexandria, it would be easier to associate his image to the conqueror's memory (Bingen, 2007: 19-20). Alexander's successors made efforts to prove their participation in the battles on his side, starting with Ptolemy that transfers the hero's body to Alexandria and associates Alexander's foundation with the new seat of his power established in Egypt (Spencer, 2002: 8).

Concerning the Ptolemaic period, the main focus of the literature is on the initial development of the new establishment and the importance of the kings in guarantying splendor and sophistication to its façade. The sources are more meager compared to the foundation context and are more focused on isolated episodes of the dynastic history. They also become more detailed as Rome's presence in Egyptian affairs is more frequent. Diodorus mentions the city's rapid development: 
In shape, it is similar to a chlamys, and it is approximately bisected by an avenue remarkable for its size and beauty. From gate to gate it runs a distance of forty furlongs; it is a plethron in width, and is bordered throughout its length with rich facades of houses and temples. Alexander gave orders to build a palace notable for its size and massiveness. And not only Alexander, but those who after him ruled Egypt down to our own time, with few exceptions have enlarged this with lavish additions. The city in general has grown so much in later times that many reckon it to be the first city of the civilized world, and it is certainly far ahead of all the rest in elegance and extent and riches and luxury. The number of its inhabitants surpasses that of those in other cities. At the time when we were in Egypt, those who kept the census returns of the population said that its free residents were more than three hundred thousand, and that the king received from the revenues of the country more than six thousand talents (Diodorus of Sicily, Bibliotheca Historica 17.52.3-6).

We can notice the quantity of adjectives used by Diodorus to describe the city, all of them associated to its greatness, richness and beauty, placing it even in front of Rome. In this way, the author gives a tip of the rumor that was circulation in his environs, about Alexandria's monumentality. He also points to its continuous growth, which is maybe the reason why he classifies the city as the first city of the world. In other words, if it maintained this rhythm of development its potential would be enormous. This commentary by Diodorus is an evidence of the metropolis' growth during the whole Ptolemaic period (Mckenzie, 2008: 75). Diodorus emphasis is especially on the importance of the kings in establishing and sophisticating the buildings, highlighting also its abundance, richness and populousness, indicating that still in his time there was a huge migratory movement to the city.

Another highlight given by Diodorus and Strabo among the achievements of the first kings is related to the transference of Alexander's body form Babylon to Egypt, by the first Ptolemy (Bibliotheca Historica 18.28.3-5). With this transference, we notice how Diodorus is once again, connecting Alexander to Alexandria, mentioning Ptolemy's denial to take his body to Amon. Namely, the body should rest in its Greek foundation, and should not be associated to Egyptian symbols. This decision had a great symbolic value, denoting the formation of a new identity in Egypt, to which Alexander and the new kingdom there installed, would be the representatives. Strabo notices that in the Sema (another part of the royal palace) rested the tombs of Alexander and the kings. Therefore, as they 
were part of the same mortuary complex, Strabo points out the strong connection between them (Erskine, 2002: 164). The author describes the harbours, temples distributions and buildings (Geographica 17.1.8). With all this structure, he underlines the importance of the city as a royal, administrative, spiritual and commercial centre, all at once. As Diodorus, Strabo's main focus is in the sumptuousness of the palace and the administrative importance of Alexandria till his days, maintaining a considerable part of its ancient splendor:

And the city contains most beautiful public precints and also the royal palaces, which constitute one-fourth or even one-third of the whole circuit of the city; for just as each of the kings, from love to splendor, was wont to add some adornment to the public monuments, so also he would invest himself at his own expense with a residence, in addition to those already built, so that now, to quote the words of the poet, "there is building upon building» (Strabo, Geographica 17.1.8).

Strabo mentions Thebes and Memphis' continuing importance as Egypt's main cult centers. Therefore, he establishes a "division of functions» between the most important cities of Egypt. Even though Strabo defines Alexandria as a new «Greek body» installed in Egypt, he inserts it in a dynamic peculiar to the country, as its foundation resulted in a transposition of other centers. Therefore, he does not dissociate Alexandria from its surroundings, in spite of being remarkable in the environs.

Concerning the body, Pausanias and Curtius mention its passage first in Memphis and then its transference to Alexandria (Graeciae descriptio. Áttica 1.6.3; Historiae Alexandri Magni 10.10.20.3), while Diodorus and Strabo relate that it was brought from Babylon (where he died) and went straight to Alexandria. The emphasis of Curtius and Pausanias in the body's route in the ancient Pharaonic capital would probably stress an Egyptian and Hellenistic parcel of Alexander's identity, which the earlier narratives do not suggest. It would then be a way to promote a form of conciliation between cultures through Alexander.

The greatness of the edifications and royal palaces are less mentioned by the Latin sources, with the exception of the lighthouse of Pharos, noticed by Caesar and Pliny (Naturalis Historiae 36.18.83.2). Concerning Alexandria's initial history, the emphasis of the sources is on the king's motivations to transform Alexandria in the legitimate seat of the reign heir of Alexander. Therefore, all the investments should be made to divulge its 
richness and power. The picture is of Alexandria as the supreme manifestation of the monumental, huge and excessive.

The accounts of the greatness of Alexandria, but also of its danger, started to be spread as a manner to increase the consciousness concerning the city's potential. In other words, it was not sufficient to publish narratives defaming its image, it was also necessary to demonstrate its important and magnificence determined by Alexander, to inform that the city had conditions to rival with Rome, if it had adequate conditions and organization (as Diodorus had suggested). The aim of these writings was to report, in an indirect way that the city was similar to Rome in several ways.

The authors offer an understanding of the Alexandria of their time, the most important commercial center of the region. The commentaries about Egypt's prosperity and Alexandria's commercial importance are present in many moments of its description. Before Egypt's conquest, the authors had already called attention to its vitality to the empire.

Cicero suggests in several moments that the relations between the roman political elite and the kingdom should be cautious, due to its prosperity (De Lege Agraria Contra Rullum 2.16.41-43; De Officis 3.12.50; Epistulae ad Atticum 2.5.1.1; Epistulae ad Atticum 9.9.2.13). In this way the author illustrates Roman dependency and susceptibility to Egyptian grain. Considering the moment he writes (context of civil war), it is plausible that he mentions Egyptian productivity as an alert, or as a reminder of the importance of taking Egypt soon. His comments imply that Egypt was already an important supplier next to Sicily during the Hellenistic period (Casson, 1984: 82).

In the scenery of war between Caesar and the Alexandrians, the report of the Alexandrian war notices the abundance of the city in many kinds of supplies (Bellum Alexandrinum 3.1.1). The author also emphasizes Alexandrian supremacy on the sea and its techniques (Bellum Alexandrinum 16.10.1). Therefore, his narrative points to the marine knowledge promoted by the founding of the harbors in a context before Roman conquest.

The literature mentions the good commercial conditions of the region in the Ptolemaic context; however they highlight even more the advances after Rome's conquest. Apart for the improvements, we must consider that the writings of the period tended to emphasize Augustus' importance in this process. Therefore, they give little importance to the prosperity and commercial routes established before the impact of the Roman peace. Consequently, if the narratives are evidences of the developments pro- 
moted by Rome, on the one hand, they are also signs of exaltation of the time, on the other.

Strabo is the most important source to analyze Alexandria's role as a form of access to the East, for he deals with the theme with the aim to make noteworthy the commercial development of his time. The author observes that, most of the aromatics coming from Arabia and India were transported through the Nile to Alexandria. The products were taken by camel to Coptos in the Thebaid, then to a channel of the Nile, and from this point they followed towards the metropolis (Geographica 16.4.24.20). In spite of Strabo's silence, there are considerable evidences indicating that before the Empire, the kings had started to exploit the commerce with the East, by building harbors in the coast of the Red Sea (Young, 2001: 19).

Although Strabo does not mention the investments promoted by the kings to develop commercialization, he does point to Egyptian closure to outsiders before the Ptolemies. Before Alexandria the access to harbors was hard and carefully watched, mainly because of pirates (Geographica 17.1.19). The author suggests the commercial opening provided by the construction of Alexandria and the installation of new harbors.

Strabo also signalizes to the importance of the internal harbor with access to Lake Mariot, where several channels of the Nile arrived. Many products came from the river and made this harbour even richer than the coastal. In this way, more articles left than arrived in this harbor (Geographica 17.1.7). Strabo once again points to Alexandria's good location as the main advantage of the city, improving commerce by land and sea. As it was the only place in Egypt with these facilities, it became the «biggest market in the inhabited world». The author justifies that the Romans introduced new taxation to improve administration, for the Ptolemies had failed in this sector, and also to stimulate the trade with the East, which had increased considerably. He also observes that in old times few boats would dare to cross the golf of Arabia, while in his time huge fleets were sent and returned to Egypt, loaded with richness and were then sent into Egypt and other regions. In this way, and Alexandria was not only the receptacle, but also an important source for the outside world (Geographica 17.1.13).

Pliny is the most important source to understand the manufacture and commercialization of papyri, advocating that the registers of «his civilization» depended on it. Romans owned its discovery to Alexander's victory when he founded Alexandria, since before, it was not widely used, and «after 
this, the use of that commodity, by which immortality is ensured to man, became universally known" (Naturalis Historiae 13.21.68-70). Pliny turns his focus to Alexandria as a center, being responsible for supplying the material that universal knowledge depended on. Therefore, its centrality in many sectors was noteworthy and escaped to Roman control, for it also benefited and was dependent on the production and innovations made in the Egyptian metropolis. While emphasizing the commercial gains in the region, Strabo and Pliny highlight also Alexandria's dynamicity.

The Jewish author Flavius Josephus also illustrates mainly the city's centrality as a distributor of products and the advantages of its geographical position. He affirms that in the Alexandrian harbor many products arrived and then the surplus were sent to the entire inhabited world (Bellum Judaicum 4.612-615).

Tacitus mentions Rome's dependency on Egyptian grain on several moments. On one occasion, he justifies that Rome did not depend on other regions of cultivation, and that they commercialized with Africa and Egypt just for preference (Annales 12.43). The fact that he denies the necessity and in other moments calls attention exactly to this need, suggests that this level of dependency on Egypt was not pleasing.

In a later context, referring to Trajan's reign, Pliny the Younger describes a time of scarcity in Egypt, when the Egyptians had to ask the Emperor for help with its internal provision (Panegyricus 30). According to Pliny, «fortune» chose Egypt to test Rome's resources and vigilance. $\mathrm{He}$ also affirms that the situation was a refutation to the ancient general belief that Rome depended on Egyptian grain, position that used to flatter Egypt. It was a proof that the capital did not depend on Egypt anymore, although the opposite was true (Panegyricus 31).

These surpluses sent by Rome to feed Alexandria were probably derived from Egypt, what Pliny sees as a Roman «revenge» and a change to the situation of dependency (Erdkamp, 2005: 228).

Although Pliny denies the need and uses his arguments as proofs of the opposite situation, his defensive posture illustrates a lamentation of Egypt as a vital supplier to Rome. Therefore, the capital's vulnerability to Egyptian grain was not pleasing to its sovereignty, as Tacitus had already suggested.

The Greek authors reinforce more Alexandria's preeminence as a commercial city, while the Latin emphasizes the specific issue of the grain supply. Alexandria's image as a rich and prosperous center in the Roman 
world is continuous in the narratives from Cicero to Pliny, suggesting that it was a strong element in the city's identity to ancient eyes.

Entertainment in Alexandria was another aspect of the city's routine that made it notorious in the surroundings. Unfortunately, we have few descriptions of all forms of leisure that took place, because they are normally treated by the literature with censure, for being understood as occasions that distracted the population. Therefore, the aim now is to point to the type of appreciation established by the authors concerning the relaxation moments and investigate how the events related to the dynamic of the city, making it even more attractive to the region, but also permanently criticized.

Alexandria did not become popular only for the frequency of festivals and celebrations, but also by a type of humor that was very badly understood by outsiders. If for Alexandrians, laughter was a characteristic aspect of their routine, for visitors it was a behavior seen as excessive and malicious. The authors also criticize their tendency to mockery and for not measuring words. Therefore, the entertainments in the city, a peculiar kind of humor, and the way the Alexandrians behaved on festive occasions become another channel to criticize its inhabitants, for being abusive and inconvenient specially for being done in multitudes.

Cicero (Pro Rabirio Postumo 12.34.2) and the anonymous author of the Alexandrian War (Bellum Alexandrinum, 7.2.5) had already pointed out to Alexandrian's nature of talking with no restraint and propagating calumnies. It was an attitude seen as theatrical and inconvenient, that made them famous. Thus, when the sources talk about the Alexandrian rebel tendency, they are not necessarily referring to their initiative to armed conflicts, and rebellions, but to their talent to spread disharmony through words.

The pattern of criticizing the leisure life in Alexandria increases during the first century $B C$ and first century $A D$, after Augustus propaganda and in the context of condemnation to Cleopatra done specially by Latin poets. The literature uses the person of the queen to promote a general image of Alexandria and Canopus as a region of pleasure and excesses.

Plutarch observes that Anthony had an immediate identification with the Alexandrians, because of his comic behavior that he disguised when in contact with Roman seriousness (Vita Antonii 29). Here the author establishes a parallel between the Alexandrian tradition to laughter, which contrasted with Roman severity (Trapp, 2004: 122). 
The Jewish Alexandrian Philo mentions an example of debauchery of a public figure in the scenario of anti-Judaism promoted by the Greeks in the city. The Alexandrians dressed a mad man in the city as the Jewish king Agrippa, who was present in the city, and made a theater in the gymnasium (In Flaccum, 36-39). In Philo's perception these clubs were the focus of mess, gossip and frequently resulted in political intrigues, as they were probably the places where the Alexandrians promoted their critiques to authorities. As a Jewish philosopher and defender of morality, Philo censures his own compatriots with the same discourse that Romans used to talk about the city. Another episode of mockery of a public figure that made the Alexandrians be punished, happened 200 years after the situation described by Philo and refers to the massacre of the Alexandrians by Caracala, narrated by Dio Cassius (Historiae Romanae 78-79) and Herodian (Herodiano 4.8-9). The authors justify that what angered the Emperor was the calumnies divulged concerning his brother's death. Especially Herodian highlighted their improper behavior, justifying that this people had a natural tendency to produce satyrs and jokes, while making fun of authorities (Herodiano 4.9.2-3).

In his philosophical works, Philo has a few comments expressing his censorship to the leisure in Alexandria. He stresses the different effects provoked in the audience of the theatre, from the more extreme excitement that made people loose control, to those who had aversion to the effects of music (De Ebrietate 177). So in his view, the theatre was a place of suffering and pleasure (SLY, 1996: 85). The author also alludes to the violence of horse races (De Agricultura 312.76; Legum Allegoriae 3.223) and illustrates the movement and vivacity of the Agora as a place of meetings and negotiation, with animal carriages circulating, frequently resulting in violence, because of the agglomerations (De Somniis 2.91, De Specialibus Legibus 3.105). Philo articulates a condemnation of all types of festivals among Greek and barbarians, and observes that the ones from his city only resulted in excesses, conflicts, insolence and offences. The author makes a list of all the bad effects of the chaos generated by the festivals and affirms that in these occasions the city was turned upside down (De Cherubim 91).

Dion of Prusa is the most important author of this thematic, for the extension and rhetorical elaboration of his account, which concentrates specifically on advising the Alexandrians about their excesses in days of festivals. He elaborates several praises to the city concerning its greatness 
and beauty, which were diminished by the character of the population. Besides being contrary to multitudes in general, like Philo, his criticism to the Alexandrians is specific, for he considers that this people had a manner of behaving in group that was incomprehensible to others. The oration was destined to the people of Alexandria, probably to the popular assembly, as it was in Greek. The date of the speech is controversial, but most authors agree on the reign of Trajan.

Dion alerts the Alexandrians to be more moderate in public spaces and to control their enthusiasm dedicated to spectacles; the euphoria was such, that they dedicated all their energy to these events, and when they needed seriousness in critical moments, they had no focus. This is the main message of the speech, but to firm his opinion, Dion elaborates a detailed narrative about Alexandria and its population, reflects about the consequences of this behavior to the city, and what would happen in case they did not change this pattern and become aware of the problem.

Dion starts denouncing that in the theatre there was only place for noise, tumult and provocations (Orationes 32.4) and clarifies that he was not advising them to give up their entertainment, but to focus on serious issues too (Orationes 32.4-6). It was specially their passion for music that made them loose their minds (Orationes 32.20).

In his aim to elaborate a criticism, the author makes a comment in which he defines Alexandria as a «world-city» for approximating all kinds of peoples, in this way he illustrates its central position in the commercialization of the Empire, defining the city as a point of worldly conversion, of products and people:

For your city is vastly superior in point of size and situation, and it is admittedly ranked second among all cities beneath the sun. For not only does the mighty nation, Egypt, constitute the framework of your city - or more accurately its appanage - but the peculiar nature of the river, when compared with all others, defies description with regard to both its marvellous habits and its usefulness; and furthermore, not only have you a monopoly of the shipping of the entire Mediterranean by reason of the beauty of your harbours, the magnitude of your fleet, and the abundance and the marketing of the products of every land, but also the outer waters that lie beyond are in your grasp, both the Red Sea and the Indian Ocean, whose name was rarely heard in former days. The result is that the trade, not merely of islands, ports, a few straits and isthmuses, but of practically the whole world is yours. For Alexandria is situated, as it were, at the cross-roads of the whole world, of even 
the most remote nations thereof, as if it were a market serving a single city, a market which brings together into one place all manner of men, displaying them to one another and, as far as possible, making them a kindred people. (Dio Chrysostom, Orationes 32. 35-36).

The author clarifies that his aim in praising the city was only to show that any act of inconvenience, would not be made in the presence of few, but in front of «all humanity» (Orationes 32.37-39). The author continues to sketch his cosmopolitan picture of the city:

For I behold among you, not merely Greeks and Italians and people from neighbouring Syria, Libya, Cilicia, nor yet Ethiopians and Arabs from more distant regions, but even Bactrians and Scythians and Persians and a few Indians, and all these help to make up the audience in your theatre and sit beside you on each occasion; therefore, while you, perchance, are listening to a single harpist, and that too a man with whom you are well acquainted, you are being listened to by countless peoples who do not know you; and while you are watching three or four charioteers, you yourselves are being watched by countless Greeks and barbarians as well.

What, then, do you suppose those people say when they have returned to their homes at the ends of the earth? Do they not say: «We have seen a city that in most respects is admirable and a spectacle that surpasses all human spectacles, with regard both to beauty and sanctuaries and multitude of inhabitants and abundance of all that man requires" going on to describe to their fellow citizens as accurately as possible all the things that I myself named a short while ago - all about the Nile, the land, and the sea, and in particular the epiphany of the god; "and yet» they will add, «it is a city that is mad over music and horse-races and in these matters behaves in a manner entirely unworthy of itself» (Dio Chrysostom, Orationes 32.40-41).

After emphasizing that the whole world was present in Alexandria, Dio highlights that all these people, going back to their homelands, would praise the city, but criticize their inhabitants. His perception is of Alexandria as a «world-city», thus it should serve as an example for all humanity and for being located in the "centre of the civilized world», it should care for its reputation (Orationes 32.45-47).

Dion's emphasis is more on the Alexandrian's confusions associated with leisure than with conflicts (Barry, 1988: 10). However, his main concern is not on their devotion to spectacles, but on the effects they had on the 
audience, leading to immoderate acts. What worried him was specially the amount of people united to attend the ceremonies, besides the attraction this agglomeration effected on those who arrived there. Thus, no place apart from Rome had the capacity of grouping such an extent and varied crowd. While putting so many universes in contact, rebellions and tumults could easily arise and achieve wide regions, and from Alexandria, rumors and ideas that challenged order could also spread. By highlighting the variety of people that circulated there, Dion suggests that such a populous city could easily become a threat to Roman order. Therefore, if chaos was there installed, it could achieve that entire universe conquered by Rome.

Suetonius also alludes to the excitement of the Alexandrians in the theatre, mentioning their enthusiastic applauses, which the emperor Nero ordered his men to learn so that every time that he sang they would cheer for him in the same way (Nero 20). Suetonius does not condemn this Alexandrian habit, although he ridicules Nero's posture to copy them. Philostratus also censures the Alexandrian's behavior in public spectacles and their devotion to horses, saying that they were destroying themselves through the lack of seriousness (5.26). Certainly, the theatre, the hippodrome and the agora were the main focus of urban agglomerations, for they were spaces that allowed the sociability of several groups and cultures. They were also places of interaction among the urban population with civic and Roman authorities, thus they could also turn into the setting of more violent demands of the population (Haas, 1997: 64-65).

Mimics were an old and well known form of entertainment in the city, which went back to Ptolemaic tradition (Musurillo, 1954: 248). It was not only used as leisure, but also in a critic manner (Harker, 2008: 119). They were more elevated in tune than other public events in the city and constantly made reference to contemporary issues (Bowman, 1986: 216). Thus, the production of satires and mockery to authorities through mimics and theatre was an old tradition in the city, although it is only referred to with criticism. Besides all the censures destined to the Alexandrians, the evidences of Philo, Dio Cassius, Dion of Prusa and Herodian suggest that through mimics, rumors and complaints were spread. Therefore it was a form of entertainment that escaped imperial control, for it disseminated questioning to contemporary and civic issues through humor. Thus, they became another motive to reprehend the Alexandrians, since the teachings induced people to become more active on civic issues. In other words: everything was done aiming for a quiet, ordered and little reflexive 
Alexandria. Consequently, publishing an image of the people's tendency to rebellion would help create an aversion to what was practiced there.

Alexandria becomes popular for its devotion to entertainment; however, as the literature only calls attention to the negative side of the diversions, we know little of the city's role as a leisure center. Focusing only on the consequences of the spectacles was a way of turning the attention from the Alexandria of pleasures, which was attracting crowds. The Roman elites would not encourage this tendency, for on the one hand it could produce chaos because of the huge agglomerations, on the other, the capital of the Empire in the entertainment sector was Rome and there should be no other.

The Alexandrian identity focused on leisure was highlighted specially by Greek authors from the end of the first century AD. Only Suetonius mentions the Alexandrians festive tendency from the perspective of a Latin, though his main ideal was to criticize Nero. Thus, the turbulent and cheerful tendency of Alexandria was not something that the Greeks wanted to reinforce. Since the city that was heir of Alexander should care for its heritage and tradition in other ways, and not by spreading chaos through leisure.

Dio Cassius and Herodian condemns the production of satires and mimics for resulting in offenses to authorities. Therefore, in these authors the criticism to leisure was specific to this kind of manifestation produced in the city, for it could affect imperial order. If the Latin authors do not mention the context after Cleopatra, it seems that it was convenient for the tradition to maintain the former picture of Alexandria as a land of excesses and pleasure.

Achilles Tatius, another Alexandrian author of the late second century $A D$, illustrates Alexandria's variety of peoples, besides stressing its enormity, beauty and vivacity. He emphasizes in a poetic manner the dynamicity of the city. The author says that as soon as his character entered the city, he was instantly impressed by its intense beauty. Tatius underlines with exaggeration the hugeness of its population, making a metaphor of the city as being bigger than a continent, due to the mixture of peoples contained in the place. The city had so many streets that walking around you would have the impression of being abroad even being home. He points out that two things impressed him particularly and it was impossible to decide which was superior: the greatness of the place and its beauty and the city or its inhabitants, for the first was huger than a continent, and the second was 
bigger than a «whole nation». He also doubted if any people could ever fill the city, and with so many inhabitants, he imagined if any city would be huge enough to protect them all (Leucippe et Clitophon 5.1). The author signalizes a fascination with the city, although he demonstrates a personal involvement for being Alexandrian, something less remarkable in Philo. Despite its poetic nature, his narrative illustrates the city's vivacity in the second century AD (Mckenzie, 2008: 188).

It is also mainly the Greek authors that draw attention to the enormity and population variety of Alexandria. To summarize, the perception of the literature was as follows: its position as a centre that agglutinated many peoples turned Alexandria into an appealing place. Besides its commercial dynamic, the people that went there were also attracted by its festivals, occasions that could result in huge crowds and generate turbulence and conflicts. Thus, it is not a coincidence that Dion of Prusa stresses mainly these two aspects: enormity and turbulence, for they were related elements. The agglomerations united could also spread rumors and «fashions" and achieve wide regions. In other words, no other place in the Empire had this talent for publicizing as Alexandria.

With Roman hegemony, many cities were tempted to imitate Roman magnificence and the huger the prestige of a metropolis, the closer and with more envy it was watched (Lendon, 2001: 77). Therefore, it is not a coincidence that Alexandria was the most (well and badly) spoken and controlled city by Rome. That is the origin of so many accounts placing Alexandria next to the capital and promoting it's classification as the second city in the Empire. The comparison does not only concern its geographical and population size, but the fact that the city became preeminent in many sectors, approaching or even exceeding Rome. Thus, so many adjectives in its characterizations served to compare it to the capital of the Empire, demonstrating its similarity and differences. That is the origin of the interest of the authors in elaborating categorizations of cities, maybe as a form to alert. Through Alexandria, Roman excellence would reflect, as in a mirror, but also its absences and faults would become more prominent.

Excessive criticism and hostility could have the intention to increase Roman's glory. In a society were fame was conquered in comparison to others, it was necessary to bring the opponent down (Marincola, 1998: 163-164). Accordingly, criticize or flatter Alexandria could reinforce or call attention to Rome's best qualities and also illustrate its fragile issues. As a result, Alexandria represented a threat to Rome for being so similar to 
it. This concern was manifest in different forms according to the transformations experienced by both cities. Under the Ptolemies, Rome relates with Alexandria by means of diplomatic bonds, then through friendly intromission on the royal affairs. Subsequently, by annexation, for the strengthening of both cities made them opponents to each other, resulting in the necessity of incorporating it to the Empire soon. And finally, through constant vigilance (three troops in Egypt) and different strategies to keep the city enclosed (with the absence of the Boule, establishing the post of prefect to equestrians and prohibitions of senators to enter the territory) since Rome was confirmed as supreme potency of the world. It was vital to keep Alexandria watched and calm, thus, the accounts of the period served as a manner to maintain the «alert» alive, that is why it was always dealt with polemics ${ }^{(2)}$.

\section{Notes}

(1) Concerning the commentaries of the Latin authors' on Alexandria, I would light to highlight the importance of a recently published article, entitled «Representations of Alexandria in Classical Latin Literature» by Professor Maria Cristina de Castro-Maia de Sousa Pimentel that also deals with ancient representations about the city. Unfortunately I did not have access to this work in time to include it in the analyses of this article. However, I would like to thank Professor Nuno Simões Rodrigues for this updated reference, which dialogues directly with my research.

(2) This article is the result of a conference presented in the Bibliotheca Alexandrina of Alexandria, Egypt, on November 12, 2012. The event was organized by Dr. Mohamed Kenawi and the The Alexandria Center for Hellenistic Studies to whom I am truly thankful. The website of the event: $h t t p: / /$ www.bibalex.org/hellenisticstudies/News/Details.aspx?ID=JVuneV7PQM1PhLuTyiTZcw\%3d\%3d.

\section{Bibliography}

BARRY, W. D., Faces of the Crowd: Popular Society and Politics of Roman Alexandria, 30 B. C. - A. D. 215. PhD Thesis - University of Michigan, 1988.

BINGEN, J., Hellenistic Egypt: Monarchy, Society, Economy, Culture, Berkeley, Los Angeles: University of California Press, 2007.

BOWMAN, A., Egypt after the Pharaos 332 B. C.-A. D. 642, Berkeley, Los Angeles, London: University of California Press, 1986.

CASSON, L., Ancient Trade and Society, Detroit: Wayne State University Press, 1984.

ERDKAMP, P., The Grain Market in the Roman Empire: A Social, Political and Economic Study, Cambridge: University Press, 2005.

ERSKINE, A., «Life after Death: Alexandria and the Body of Alexander», G\&R 49/2, 2002, 163-179. 
FEENEY, D., Literature and religion at Rome: Culture, Contexts, and Beliefs, Cambridge: University Press, 1998.

HAAS, C., Alexandria in Late Antiquity: Topography and Social Conflict, Baltimore, London: The Johns Hopkins University Press, 1997.

HARKER, A. A., Loyalty and Dissidence in Roman Egypt: the case of the Acta Alexandrinorum, Cambridge: University Press, 2008.

KNOX, B. M. W., "Books and reader in the Greek world: from the beginnings to Alexandria", in The Cambridge History of classical literature. Vol. I: Greek Literature, Cambridge: University Press, 1985, 1-41.

KRASILNIKOFF, J. A., «Alexandria as Place: Tempo-Spatial Traits of Royal Ideology in Early Ptolemaic Egypt», in Hinge, G.; Krasilnikoff, J. A., eds., Alexandria. A Cultural and Religious Melting Pot, Aarhus: University Press, 2009, 21-41.

LENDON, J., The Empire of Honour: the Art of Government in the Roman world, Oxford: University Press, 2001.

MARINCOLA, J., Authority and Tradition in Ancient Historiography, Cambridge: University Press, 1997.

MCKENZIE, J., The Architecture of Alexandria and Egypt: 300 B. C. to A. D. 700, London: Prestel, 2008.

MUSURILLO, H., Acts of the Pagan Martyrs, New York: Oxford University Press, 1954.

PIMENTEL, M. C. C.-M. S., «Representations of Alexandria in Classical Latin Literature» in: Sousa, R., Fialho, M. C.; Haggag, M.; Rodrigues, N. S., eds., Alexandrea ad Aegyptum - The Legacy of Multiculturalism in Antiquity, Porto: Afrontamento/CITCEM, 2013, 48-61.

RUNIA, D. T., «Polis and Megalopolis: Philo and the Founding of Alexandria», Mnemosyne 42/3-4, 1989, 398-412.

SLY, D., Philo's Alexandria, London: Routledge, 1996.

SPENCER, D., The Roman Alexander: Reading a Cultural Myth, Exeter: University of Exeter Press, 2002.

SWAIN, S., Hellenism and Empire: Language, Classicism, and Power in the Greek World AD 50-250, Oxford: Claredon Press, 1996.

TRAPP, M. B., «Images of Alexandria in the writings of the Second Sophistic», in HIRST, A.; SILK, M., eds., Alexandria, Real and Imagined, Aldershot: Ashgate Publishing Ltd., 2004, 113-132.

YOUNG, G., Rome's Eastern Trade. International Commerce and Imperial Policy, 31 BC-AD 305, London: Routledge, 2001.

VASUNIA, P., The Gift of the Nile. Hellenizing Egypt from Aeschylus to Alexander, Berkeley, Los Angeles, London: University of California Press, 2001. 